\title{
GAGASAN HUMAN SECURITY DALAM KEBIJAKAN PERSONAL SECURITY TINJAUAN TERHADAP DRAFT RANCANGAN UNDANG-UNDANG PENGHAPUSAN KEKERASAN SEKSUAL DAN PERBANDINGANNYA DENGAN KEBIJAKAN KEKERASAN SEKSUAL DI JEPANG
}

\author{
Jovanscha Qisty Adinda FA \\ Program Studi Magister Kebijakan Publik \\ Fakultas Ilmu Sosial dan Ilmu Politik \\ Universitas Padjajaran \\ jovanscha@gmail.com
}

\begin{abstract}
ABSTRAK
Human Security adalah sah satu bentuk dari perkembangan Keamanan yang dulunya hanya berfokus pada kedaulatan negara, sekarang fokus utama dari keamanan br pindah kepada manusia, didalam human security, terdapat beberapa tipe/ bentuk keamanan salah satunya adalah Personal Security yang dimana dala pembahasnya salah satunya menyebutkan tentang kekerasan seksual sebagai bentuk Sexual Violence, Indonesia sebagai salah satu negara yang menjamin keamanan masyarakatnya sudah sepatutnya berfokus pada pencegahan Kekerasan Seksual, hal ini ditunjukan dari adanya RUU Penghapusan Kekerasan Seksual yang berfokus melindungi masyarakat secara detil membahas berbagai macam perlindungan atas tindak kekerasan seksual, RUU Penghapusan Kekerasan Seksual ini dianggap dapat mewadahi kebuthan akan peningkatan dalam ranah Personal Security karena jika ditelaah lebih lanjut isi dari RUU ini secara detil membahas beberapa hal yang tidak terbahas dalam kebijakan lain, seoerti perlindungan korban, saksi dan ahli, atupun hak-hak yang dapat diterima korban kekerasan seksual. Jika dibandingkan dengan Jepang, Indonesia sudah selangkah lebih maju menghadapi maslaah human security khusus katagori Personal Security.
\end{abstract}

\begin{abstract}
Human Security is a legitimate form of security development that used to focus solely on sovereignty, now the main focus of security is shifting to humans, in human security, there are several types/forms of security, one of which is Personal Security where one of them mentions violence Sexuality as a form of Sexual Violence, Indonesia as one of the countries that guarantee the security of its people should focus on preventing Sexual Violence, this is explained by the Bill on the Elimination of Sexual Violence which focuses on protecting the community in detail discussing various types of protection against sexual violence, Bill on the Elimination of Violence Sexuality is considered to be able to accommodate the need for improvement in the realm of Personal Security because if it is examined further, the contents of this bill in detail discuss some matters that are not discussed in other policies, such as the protection of victims, witnesses, and experts. $k$ rights that can be accepted victims of sexual violence. When compared to Japan, Indonesia is one step ahead to face the human security problem specifically in the category of Personal Security.
\end{abstract}

\section{PENDAHULUAN}

Keamanan (security) secara umum dapat didefiniskan sebagai kemampuan mempertahankan diri (survival) dalam menghadapi ancaman yang nyata. Barry Buzan yang dalam bukunya People, States, and Fear mengatakan bahwa:

"security, in any objective sense, measures the absence of threat to acquired values, in a subjective sense, the absence of fear that such values will be attacked" (Buzan, 1991:4).
Gagasan human security dewasa ini merupakan reaksi terhadap masalah- masalah kemanusiaan yang melanda dunia saat ini, seperti pengungsi akibat konflik dan kekerasan fisik, perdagangan anak-anak dan wanita, masalah pangan, terorisme, perdagangan senjata ilegal, pelanggaran hak azasi manusia (HAM), dan sebagainya.

Konsep Human Security Merupakan konsep keamanan yang semakin mendapatkan perhatian karena melihat negara yang sangat dominan dalam mendefinisikan, membuat serta menerapkan kebijakan 
keamanan berdasarkan teritorial, kalkulasi militer dan stabilitas politik dan justru mengesampingkan kepentingan atau kebutuhan orang per orang akan keamanan yang lebih komprehensif.

UNDP merinci tujuh komponen keamanan manusia yang harus mendapat perhatian yakni, 1) economic security (bebas dari kemiskinan dan jaminan pemenuhan kebutuhan hidup, 2) food security (kemudahan akses terhadap kebutuhan pangan), 3) health security (kemudahan mendapatkan layanan kesehatan dan proteksi dari penyakit), 4) environmental security (proteksi dari polusi udara dan pencemaran lingkungan, serta akses terhadap air dan udara bersih), 5) personal security (keselamatan dari ancaman fisik yang diakibatkan oleh perang, kekerasan domestik, kriminalitas, penggunaan obat-obatan terlarang, dan bahkan kecelakaan lalu lintas), 6) community security (kelestarian identitas kultural dan tradisi budaya), dan 7) political security (perlindungan terhadap hak asasi manusia dan kebebasan dari tekanan politik).

Diantara tujuh komponen keamanan yang dirinci diatas, terdapat komponen yang membahas personal security, pengrtian personal security menurut Franklin D. Roosevelt, yang terkait dengan empat jenis kebebasan yang melekat pada setiap orang: kebebasan berbicara dan berekspresi, kebebasan untuk menyembah Tuhan dengan milik sendiri cara, kebebasan dari keinginan, dan kebebasan dari ketakutan. ${ }^{1}$ Pada dasarnya keamanan pribadi merupakan hal yang melekat pada diri manusia

Menurut United Nation ${ }^{2}$ ada beberapa jenis yang termasuk kedalam personal security

- Sexual violence, sexual assault

- Arrest, detention

- Hostage taking

- Crowds, protests and demonstrations

- Landmines

- Weapons firing

- Hijacking

Indeonsia sendiri dinilai sedang memsuki fase darurat kekerasan sexual, atau dapat disebut dalam physical violence beberapa kasus kekerasan seksual yang mulai banyak diangkat kepublik menunjukan mulai adanya perhatian yang sangat signifikan terhadap masalah kekerasan seksual, bebrapa kasus diantaranya adalah WA (15) seorang remaja putri asal Jambi yang diperkosa hingga hamil oleh kakak kandungnya, AA (18). ${ }^{3}$ kisah Baiq Nuril (40), mantan guru honorer SMAN 7 Mataram. Ia dikriminalisasi oleh Muslim, kepala sekolah SMAN 7 Mataram, karena merekam

\footnotetext{
${ }^{1}$ Hak Asasi Manusia Di Indonesia Di Tinjau Dari Berbagai Aspek Kehidupan, Dewi Lestari S.H, urnal Hukum dan Pembangunan Tahun ke-3 No.4

Oktober-Desember. 2007

2 Personal Security Awarness Modul 3 : Individual Peacekeeping
}

percakapan telepon antara Muslim dan dirinya yang diduga bermuatan pelecehan verbal. ${ }^{4}$ Dalam catatan Komnas Perempuan, terdapat 1.210 kasus inses, yang diikuti dengan perkosaan (619 kasus), persetubuhan/ eksploitasi seksual (555 kasus), pencabulan (379 kasus), marital rape (172 kasus), pelecehan seksual (32 kasus), kekerasan seksual lain (10 kasus), dan percobaan perkosaan (2 kasus). Kasus yang dipaparkan tersebut adalah kasus yang terlapor di beberapa komisi perilundungan perempuan, banyak sekali kasus yang belum terangkat atau tidak diketahui oleh publik.

Pada tanggal 12 Oktober 2016, pemerintah mengeluarkan draft rancangan undang-undang penghapusan kekerasan seksual, didalamnya memuat beberapa poin yang belum terakomodir produk hukum yang dimiliki Indonesia, namun rancangan undangundang ini masih belum kunjung disahkan oleh pemerintah karena masih terdapat kontradiksi pendapat dari beberapa komisi di DPR dengan alasan RUU Penghapusan kekerasan seksual ini

Jepang terkenal dengan sistem pendidikannya yang maju, wajib dan gratis. Memiliki salah satu sistem pendidikan dengan kinerja tertinggi di dunia memang merupakan faktor positif dalam hal perkembangan anakanak. Namun, tingkat pendidikan yang tinggi telah menyebabkan berbagai masalah sosial yang mungkin mengarah pada eksploitasi seksual tidak hanya pada anak-anak, tetapi juga pada orang dewasa terutama perempuan.

Tidak ada keraguan bahwa lingkungan pendidikan yang penuh tekanan dan keras mengambil korban besar pada anak-anak maupun orang dewasa dengan mendorong mereka untuk berpartisipasi dalam kompetisi yang kejam, menimbulkan tugas keunggulan, menghasut tekanan teman sebaya, dan menyebabkan beban psikologis lainnya.

Dilansir dari Tempo, maraknya aksi \#MeToo solidartias dunia untuk para penyintas dan korba pelecehan seksual juga ikut menggoyangkan pemerintah japing, Junichi Fukuda dituding melakukan pelecehan seksual terhadap sejumplah jurnalis wanita yang terekam audio recorder, hal ini memicu banyak penyintas pelecehan seksusal untuk keluarg mengungkap apa yang mereka alami terkait pelecehan seksual, menurut Profesur Ilmu Politik di Universitas Tokyo mengungkapkan alasan mengapa gerakan \#MeToo kurang popular di Jepang sehingga para penyintas malah mendapat banyak kritik,

"Dalam sebuah masyarakat patriarki dimana kebanyakan wanita terus dijadikan

${ }^{3}$ Diakses melalui https://tirto.id/beban-dan-lukakorban-pemerkosaan-inses-cP1L

${ }^{4}$ diakses melalui https://tirto.id/baiq-nuril-dikasihgunung-emas-pun-enggak-mau-saya-mau-keadilanc98Q 
Gagasan Human Security Dalam Kebijakan Personal Security Tinjauan Terhadap Draft Rancangan Undang-Undang Penghapusan Kekerasan Seksual Dan Perbandingannya Dengan Kebijakan Kekerasan Seksual Di Jepang

(Jovanscha Qisty Adinda FA)

pihak yang bersalah, banyak korban kemudian mencoba melupakan serangan dan pelecehan daripada mencari dukungan dan keadilan”

Republika, Kamis 1 Maret 2018

Artinya dapat disimpulkan bahwa Jepang saat ini mempunyai posisi yang sama dengan Indonesia yaitu mempunyai darurat penghapusan kekerasan seksual, oleh karena itulah peneliti tertarik untuk menarik simpul perbandingan antara kebijakan Rancangan Undangundang kekerasan seksual dengan Kebijakan Pemerintah Jepang dalam melindungi keamanan personal warganegaranya.

\section{METODELOGI}

Metode yang digunakan untuk penelitian ini meruju pada Reporting Items/ penelitian terdahulu untuk Systematic Reviews dengan kriiteria pemilihan penelitian adalah Peneliti secara sistematis mencari basis data bahasa Indonesia Inggris dan Jepang untuk artikel yang mengukur prevalensi kebijakan yang berlaku di Indonesia juga di Jepang, selain itu peneliti juga mencari data kekerasan seksual yang terjadi di berbagai negara sebagai referensi pondasi masalah, selain menggunakan jurnal yang telah diterbitkan, peneliti juga menggunakan berbagai sumber terutama berbagai modul yang digunakan oleh United Nation untuk mendefinisikan Human Security dan Personal Security.

\section{HASIL PEMBAHASAN}

\section{Gagasan Human Security dalam Kajian Keamanan}

Dalam perdebatan dalam Commision Human Security mendesak adanya paradigm baru dalam konsep keamanan, paradigma tersebut muncul atas 2 konsep $^{5}$ :

- Pertama, Keamanan manusia dirasa perlu dalam menghadapi kompleksitas keamanan lama dan baru dari berbagai isu yang berkaitan dengan manusia seperti kemiskinan kornis, kekerasan etnis, perdagangan manusia, perubahan iklim, kesehatan, terrosime internasional, dan krisis ekonomi keunagan. Isu-isu baru yang muncul lebih luas dibandingkan pengertian tradisonal keamanan yang berfokus pada agresi militer eksternal.

- Kedua, Keamanan manusia diperlukan sebagai pendekatan komperhensif yang dapaat mengatasdai ancaman-anacaman baru yang

\footnotetext{
5 United Nation, Human Security Theory and

Practic hal 6

${ }^{6}$ Diakses melalui

https://www.britannica.com/topic/human-security
}

lebih luas secara terpadu yang tidak dapat ditangani oleh mekanisme tradisional, saat ini dunia membutuhkan konsep baru yang merangkym keterkitan antara pembangunan, hak asasi manusia dan keamanan nasional

Konsep keamanan manusia mewakili keberangkatan dari studi keamanan ortodoks, yang berfokus pada keamanan negara. Subyek dari pendekatan keamanan manusia adalah individu, dan tujuan akhirnya adalah perlindungan orang-orang dari ancaman tradisional (mis., Militer) dan nontradisional seperti kemiskinan dan penyakit. Memindahkan agenda keamanan di luar keamanan negara tidak berarti menggantikannya tetapi lebih melibatkan pelengkap dan pengembangan di atasnya. Inti dari pendekatan ini adalah pemahaman bahwa perampasan keamanan manusia dapat merusak perdamaian dan stabilitas di dalam dan di antara negara-negara, sedangkan penekanan yang berlebihan pada keamanan negara dapat merusak kesejahteraan manusia. Negara tetap menjadi penyedia utama keamanan, tetapi keamanan negara bukanlah kondisi yang memadai untuk kesejahteraan manusia.

Gagasan memperluas konsep keamanan dari keamanan negara ke manusia secara individu diungkapkan pertama kali oleh Komisi Independen tentang Perlucutan Senjata dan Masalah Keamanan pada tahun 1982. ${ }^{6}$ Masalah kemanusiaan yang semakin banyak muncul ke permukaan menuntut tebentuknya kebutuhan akan keamananan manusia, PBB menekankan bahwa perbuhan konsep dan fokus keamanan dari keamanan yang menitikberatkan kepada keamanan negara menjadi keamanan masyarakat, dari keamanan melalui kekuatan militer menuju keamanan melalui pembangunan masyarakat, dari keamanan wilayah kepada keamanan manusia terkait jaminan keamanan, pangan, pekerjaan dan lingkungan. Menurut $\mathrm{UNDP}^{7}$ konsep keamanan yang lebih luas yangmenempatkan individu sebagai objek pusat dari semua upaya, keamananmanusia bukan hanya perihal perang antar negara, teati merupakan gagasan keamanan yang komperhensid, yang secara luas didefinisikan mencakup bebesan dari ketatukan, kebebasan dari kebutuhan dasar, dan ketersediaanya perlinduangan hak asasi manusia.

\section{Kebijakan Penghapusan Kekerasan Seksual di Jepang}

Menurut Departemen Kepolisian Kota Besar Tokyo ${ }^{8}, 1.750$ kasus pelecehan atau penganiayaan

\footnotetext{
${ }^{8}$ Diakes melalui https:/id.globalvoices.org/2018/08/22/apa-yangterjadi-saat-perempuan-melaporkan-pelecehanseksual-di-jepang/
} 
seksual dilaporkan pada 2017. Lebih dari 50 persen kasus pelecehan seksual terjadi di dalam kereta, dengan perkiraan 20 persen kasus terjadi di kawasan stasiun kereta, menurut laporan tersebut. Meskipun demikian, para penyintas tindak pelecehan seksual di Jepang sering menyesal karena jalur tuntutan hukum untuk kasus pelecehan seksual sulit diproses.

Pada tahun 2017, Legislator di Jepang mengubah beberapa kebijakan yang berlaku, yang ternyata justru dianggap memberatkan korban, bahwa Jaksa harus dapat membuktikan korban kekerasan seksual tidak bisa melakukan perlawanan, barulah pelaku tersebut dapat melakukan proses berikutnya.

Berbeda dengan peraturan untuk penghapusan kekerasan seksual secara umum dan menyeluru, Jepang punya konsentrsi khusus untuk perlindungan kekerasan terhadapa anak. Undang-undang pencegahan kekerasan terhadap anak di Jepang dikenal sebagai UU Pencegahan Kekerasan Terhadap Anak, sebekumnya di Jepang terdapat UU Kesejahteraan Anak dsebagai hukum untuk melindungi kesejahteraan anak-anak. Untuk anak-anak usia 18 tahun keatas wajib mengerahui apa itu kekerasan terhadap anak, dan terdapat pula perlindungan sementara jika disinyalir terdapat tindakan kekerasan seksuan, melalui klaim kepada pengadilan keluarga, Pada tahun 1990, ketika statistik mulai dikumpulkan, ada 1.101 insiden, dan "Reformasi Undang-Undang Pencegahan Pelecehan Anak, dll." Yang pertama. dibuat, dengan mempertimbangkan peningkatan cepat dalam pelecehan anak, dan mulai berlaku sejak 1 Oktober 2004. Dalam revisi tersebut, tujuan hukum dalam Pasal 1 pertama kali ditinjau sebagai berikut.

- Abuse Pelecehan anak adalah pelanggaran serius terhadap hak asasi anak-anak, dan menimbulkan kekhawatiran tentang perkembangan generasi masa depan negara kita

- Menentukan tanggung jawab negara dan organisasi publik lokal mengenai pencegahan kekerasan terhadap anak dan pencegahan deteksi dini dan kekerasan terhadap anak lainnya

- Untuk menetapkan langkah-langkah perlindungan anak yang menerima pelecehan anak dan dukungan kemandirian

Menentukan bahwa "pelecehan anak adalah pelecehan hak asasi manusia yang serius" adalah keinginan utama mereka yang terlibat dalam perlindungan dan pengembangan anak-anak dan peneliti. Fakta bahwa tujuan ini ditulis adalah hasil yang

\footnotetext{
${ }^{9}$ C.Burns, Sexual Violence and The Law in Japan, January 2005
}

memiliki dampak besar pada tindakan selanjutnya terhadap pelecehan anak.

Di Jepang, para korban tidak melaporkan pemerkosaan karena sejumlah alasan, termasuk ketakutan akan ancaman dan kekerasan lebih lanjut dari pelaku, perasaan malu dan malu, dan keyakinan bahwa membicarakan serangan itu tidak ada gunanya ${ }^{9}$ kebijakan yang berlaku di jepang mengenai kekerasan seksual masih diatur secara umum dan belum terperinci dan spesifik, sehingga tingkat kekerasan seksual di muka umum di Jepang masih sangat tinggi dan rawan. Hal tersebut diatur dalam Penal Code, Part 1 General Provisions, Chapter XXII Crimes of Obscenity, Rape and Bigamy ${ }^{10}$, didalamny masih berpusat pada tuntutan pada pelaku kejahatan dan belum spesifik pada korban dan pemulihan korban.

\section{Gagasan Human Security dalam Kebijakan Personal Security; Tinjauan terhadap Draft Rancangan Undang Undang Kekerasan Seksual}

Konsep keamanan manusia mempunyai beberapa tipe keamanan salah satuny adalah keamanan individu dimana menurut UNDP ancaman terhadap individu dapat datang dari negara dalam bentuk penyiksaan, akibat perang, sekelompok orang dalam bentuk ketegangan antara kelompok dan etnis, kejahatan antar individu, insdustri tempat kerca, kecelakaan lalu lintas, dan sebagainya, dalam personal security teradapat beberapa anacaman yang spesifik dapat terjadi ${ }^{11 .}$

1. Sexual violence, sexual assault

2. Arrest, detention

3. Hostage taking

4. Crowds, protest and demonstration

5. Landmines

6. Weapon firing

7. Hijacking

Kebutuhan akan adanya ekmanan yang melindungi secara detail tentang bebrap adpoin diatas juga dirasakan oleh Indeonsia, salah satu poin yang juga menjadi perhatian adalah personal security dalam isu sexual violence and/or sexual assault. Banyak yang tidak sadar bahwa sebenarnya Indeonsia sudah memasuki tingkat darurat kekeraan seksual, banyaknya perilaku yang masyarakat yang tidak sadar melakukan kekerasan seksual sampai yang sadar melakukan kekerasan seksual meningkat, hal ini menjadi sebuah ancaman baik secara individu maupun negara, bahwa tingkat rasa aman di masyarakat making menurun. Komisi Nasional Anti Kekerasan terhadap Perempuan mengeluarkan catatan

${ }^{10}$ Diakses melalui http://www.japaneselawtranslation.go.jp/law/detail/? id $=1960 \& \mathrm{re}=02 \& \mathrm{vm}=04$

${ }^{11}$ UN Core Pre-Deployment Training Materials 


\section{Gagasan Human Security Dalam Kebijakan Personal Security Tinjauan Terhadap Draft Rancangan Undang-Undang Penghapusan Kekerasan Seksual Dan Perbandingannya Dengan Kebijakan Kekerasan Seksual Di Jepang (Jovanscha Qisty Adinda FA)}

tahunanan mengenai tingkat kekerasan terhadap perempuan di Indonesia. Pengaduan kasus kekerasan naik 14\% dari tahun $2018^{12}$. Pelaporan kasus Marital Rape (perkosaan dalam perkawinan) mengalami peningkatan pada tahun 2018. Hubungan seksual dengan cara yang tidak diinginkan dan menyebabkan penderitaan terhadap isteri ini, mencapai 195 kasus pada tahun 2018. Mayoritas kasus perkosaan dalam perkawinan dilaporkan ke Dinas Pemberdayaan Perempuan dan Perlindungan Anak serta P2TP2A (sebanyak 138 kasus), selebihnya dilaporkan ke organisasi masyarakat dan lembaga lainnya ${ }^{13}$ dalam catatan tersebut diungkapkan pula oengaduan kasusu kekerasan adlam pacaran kepada institusi pemerintah, sebuah hukuman tanpa dasr hukum yang legal tapi fenomenanya hadir nyata di kalangan masyarakat dan tak dapat dipungkiri, sebnyak 2073 kasus yang masuk kadalam Komnas Perempuan dengan bentu kekerasan yang berupa. Selain dalam bentuk kekerasan secara langsung, kekerasan seksual yang paling tinggi dialami juga kekerasan seksual di dunia cyber, hal ini juga mengindikasi bahwa ancaman yang terjadi kepada individu tidak hanya pendekatan secara langsugn tetapi juga sudah memasuki ancaman keamanan individu dalam bidang teknologi dan infomarsi dimana Penggunaan teknologi untuk menyebarkan kontenkonten yang merusak reputasi korban (malicious distribution) merupakan kekerasan berbasis cyber yang dominan terjadi pada tahun 2018, selain dalam ranah individu, menurut Komans Perempuan, kekerasan seksual juga terjadi dalam ranah negara yang notabene adalah lapis utama perlindungan ekamanan individu, Pada ranah negara atau dengan pelaku negara, jumlah kasus tertinggi yang dilaporkan ke Komnas Perempuan adalah kasus kekerasan terhadap perempuan akibat pemberlakuan kebijakan diskriminatif, kebijakan tata ruang dan eksploitasi sumber daya alam.

Banyak prespektif lain yang juga terangkum dalam kasus kekerasan seksual, melihat hal ini maka ancaman terhadap kekerasan seksualpun makin nyata terlihat, negara selaku lapis utama perlindungan terhadap ancaman telah melihat hal ini sebagai salah satu yang harus segra dikaji dan dibahas agar segera bertindak. Lewat alur kebijakan pemerintah membuat Rancangan Udnang-undang penghapusan kekersan seksual yang masih belum disahkan. Didalmnya RUU Penghapusan Kekerasan Seksual akan mengatur jenisjenis tindak pidana kekerasan seksual selain eksploitasi seksual. RUU Penghapusan Kekerasan Seksual juga

\footnotetext{
12 Catatan Akhir Tahun Komisis Anti Kekerasan

Terhadap perempuan

${ }^{13}$ diakses melalui

https://www.komnasperempuan.go.id/read-newssiaran-pers-catatan-tahunan-catahu-komnasperempuan-2019
}

memberikan perlindungan tidak hanya bagi anak yang menjadi korban dari tindak pidana kekerasan seksual termasuk eksploitasi seksual, melainkan bagi setiap orang yang menjadi korban tindak pidana kekerasan seksual. Penjabaran mengenai hak korban atas perlindungan, penanganan dan pemulihan juga diuraikan oleh RUU Penghapusan Kekerasan Seksual. Didalam RUU Penghapusan kekerasan seksual focus pemulihan korban juga menajadi salah satu focus yang luput dari pasal-pasal sebelumnya, oleh karenanya berbagai ketentuan ddidalnya merupakaan pemaknaan dari kekersana seksual sebagai kejahatan luarbiasa segera penangannya harus dilakukan secara ssitematis dan terpadu dalam setiap prosesnya.

Menurut Mark. A Drumble ${ }^{14}$ kejahatan tersebut dipandang sebagai suatu kejahatan luar biasa karena memiliki kriteria utama "is conduct - planned, systematized, and organized - that targets large numbers of individuals based on their actual or perceived membership in a particular group that has become selected as a target on discriminatory grounds" pada akhirnya kejahatan luar biasa adalah suatu hal yang mengancam keamanan individu maka dari itulah mengapa RUU Penghapusan Kekerasan Seksual penting untuk terus dikaji, diperbaiki dan disahkan.

Gagasan Keamanan Manusia dalam RUU Penghapusan Kekerasan Seksual dokumen itu terdiri dari 16 bab. Dalam RUU tersebut, poin pemeriksaan tertulis dalam Bab VII bagian kelima, pasal 60 sampai pasal 66. Dalam Asas dan Tujuan pada RUU tersebut dikatakan bahwa tujuan dari RUU Penghapusan Kekerasan Seksual, dimana RUU ini memiliki memiliki asas dan tujuan untuk melindungi korban, menegakan kadilan, memberikan kepastian hukum, mencegah, dan hal lainnya yang dapat kita simpulkan dari tujuan itu semua adalah memberikan rasa aman bagi masyarakat yang tinggal di Indonesia. Selain itu pula hal lain yang juga sangat jelas bahwa beberapa pasal didalam RUU penghapusan Kekersan Seksual juga sering kali membahas tentang keamanan akan Korban, Saksi, dan Ahli dimana artinya RUU ini menjamin freedom of fears, artinya RUU Pneghapusan Kekerasan Seksual ini juga menjamin keamanan dari berabgai pihak yang terkait agar keadilan dapat diberlakukan dan rasa aman terbangun.

Selain itu dalam RUU Penghapusan Kekerasan Seksual iin juga membahas beberap apoin yang tidak dibahas oleh kebijakan lain, RUU Penghapusan Kekerasan Seksual mencakup mulai dari pencegahan ${ }^{15}$,

\footnotetext{
${ }^{14}$ Mark Durmbl, Atrocity, Punishment, and International Law, 2007, Cambridge University Press, United Kingdom. hal 4

${ }^{15}$ Diakses melalui https://nasional.kompas.com/read/2017/11/24/17393 651/apa-saja-yang-diatur-dalam-ruu-penghapusankekerasan-seksual
} 
pemenuhan hak korban, pemulihan korban hingga mengatur tentang penanganan selama proses hukum. RUU Penghapusan Kekerasan Seksual termasuk dalam undang-undang khusus atau lex specialis, dalam RUU Penghapusan Kekerasan seksual juga memebantu terbangunnya kesadaran terhadap Human Security karena beberapa pasal mendorong komnitas sekitar seperti RT dan RW sebagai kelompok komunitas yang berada di grass root untuk mengambil bagian ketika melihat adanya kekerasan seksual di lingkungan mereka, RUU Penghapusan Kekerasan Seksual ini menjamin keamanan mereka didaamnya, beberapa Hak yang diporek Korban diatur dengan jelas dalam Bab VI termasuk Hak Keluarga korban dan Hak Saksi, sehingga ketakutan akan terancamnya keamanan individu ini tiadk akan terjadi dan tujuan untuk meningkatkan Keamanan Individu ini diharapkan dapat terwujud.

\section{Kesimpulan dan Saran}

Pada hakikatnya, rasa aman adalah suatu hak dan keinginan yang melekat pada diri manusia, perkembangan yang terjadi dalam keamanan dunia adalah kecenderungan yang dahulu di fokuskan pada keamnan negara lebih cenderung membahas tentang kedaulatan. Saat ini kebutuhan keamanan sudah berpindah fokus pada keamanan dengan isu manusia. Human Security mempunyai beberapa tipe salahsatunya adalah Personal Security yang didalamnya memuat tentang bagaiamana manusia juga mempunyai beberapa isu yang mengancam keanan personal mereka, salah satu isu tersebut adalaj Kekerasan Seksual (Sexual Violence) mengapa kemudian penulis mengangkat masalah RUU Penghapusan Kekerasan Seksual adalah penulis melihat kaasus yang bersangkutan dengan keamanan individu ini dapat terus bergerak dan berkembang semakin tinggi ketika tidak dikenadilakn oleh pemetintah dalam bentuk peraturan, kasus Kekersasan Seksual ini tergolong dalam Personal Security yang harus segera diperhatikan oleh pemerintah seabagai salah satu bentuk dari penegakan Human Security peraturan yang ada dalam RUU Penghapusan Kekerasan Seksual diperlakukan untuknmengatur hal-hal yang belum diatur dalam undang-undang yang lain. Pemerintah dan DPR RI perlu segera membahas dan mensahkan RUU Penghapusan Kekerasan Seksual, untuk menghentikan impunitas bagi pelaku kekerasan seksual dan membuka akses korban atas kebenaran, keadilan, pemulihan dan jaminan atas ketidakberulangan, termasuk dalam hal ini menyetarakan posisi perempuan di depan hukum untuk mendapatkan perlindungan sepenuhnya atas tindakan pelanggaran hukum.

Jika dibandingkan dengan Jepang, Indonesia sudah selangkah lebih maju menghadapi maslaah human security khususnya katagori Personal Security, tetapi sayangnya belum ada pengesahan yang membuat peratuanini legal dengan beberapa alsan yang secara akademis dan ilmiah tidak dapat dijabarkan, untuk kemduain dipertinjau kembali, personal security dalam focus sexual harassment sedang dalam sorotan dunia, dimana banyak penyintas yang terbuka menceritakan ataupun memebrikan pengalamannya terhadap hal tersebut, dan Indonesia melalui RUU Penghapusan Kekerasasn Seksual harusnya dapt menjadi pioneer negara yang secara maksimal melindungi keamanan bangsanya.

\section{Referensi}

Catatan Akhir Tahun Komisis Anti Kekerasan Terhadap perempuan

Diakses melalui https://nasional.kompas.com/read/2017/11/24/1739365 1/apa-saja-yang-diatur-dalam-ruu-penghapusankekerasan-seksual

Diakses melalui https://irto.id/baiq-nurildikasih-gunung-emas-pun-enggak-mau-saya-maukeadilan-c98Q

Diakses melalui https://tirto.id/beban-danluka-korban-pemerkosaan-inses-cP1L

Diakses melalui https://www.komnasperempuan.go.id/read-newssiaran-pers-catatan-tahunan-catahu-komnasperempuan-2019

Diakses melalui

https://www.britannica.com/topic/human-security

Hak Asasi Manusia Di Indonesia Di Tinjau Dari Berbagai Aspek Kehidupan, Dewi Lestari S.H, urnal Hukum dan Pembangunan Tahun ke-3 No.4 Oktober Desember. 2007

Mark Durmbl, Atrocity, Punishment, and International Law, 2007, Cambridge University Press, United Kingdom. hal 4

Personal Security Awarness Modul 3 : Individual Peacekeeping UN Core Pre-Deployment Training Materials United Nation, Human Security Theory and Practic hal 6 